\title{
Decoding Tableaux Vivants: the Metareferential Potential of Painterly References in Cinema
}

\author{
Cristian Eduard Drăgan \\ University of Bucharest (Romania) \\ E-mail: cristian.eduard.dragan@gmail.com
}

\begin{abstract}
The article focuses on the intermedial relationship between cinema and painting, viewed as a self-referential process, and tries to determine various ways in which this type of signifying process can be used to "encode" various messages (within the work itself), or become an integral part of this (meta)communicative operation. Starting from a broad definition of intermedial references and continuing with a brief recontextualized detour through Gérard Genette's taxonomy of transtextual instances, the author narrows down a specific technique that exemplifies this type of "codifying" procedure, namely the tableau vivant. In accordance with Werner Wolf's proposed terminology, he attempts to determine the metareferential potential of this extra-compositional self-referential technique. The case studies focus on films by Peter Greenaway and Lars von Trier.
\end{abstract}

Keywords: metareference, self-reference, intermediality, tableau vivant, metacinema, picturality.

This paper considers the (more or less) direct manner in which the medium of cinema and painting interconnect. I shall attempt to sketch out some of the ways these types of intermedial references function in narrative cinema, and by this, I am referring to those special cases when films emulate not only the specificities of the medium of painting but also attempt to refer to specific works (in a more or less direct manner). This is by no account an exhaustive survey but an exploratory endeavour.

\section{Painterly References as Intermedial Transformative Incorporations}

Ágnes Pethő proposes two basic templates of perceiving intermediality within the cinematic medium: firstly, a "sensual" mode that brings closer the "reality" portrayed within the representations as a collection of "entangled synesthetic 
sensations" (2011, 99); and a "structural" mode "that makes the media components of cinema visible, and exposes the layers of multimediality that constitute the "fabric" of the cinematic medium, revealing at the same time the mesh of their complex interactions" $(2011,99)$. It is on this second template that I wish to concentrate within the present article. The intent is to focus on the intermedial references to painting, more exactly, solely on those instances where the visibility of the referential link is made quite clear (as to be immediately recognized by the viewer). In doing so, my hypothesis is that such intermedial instances can be used to encode specific (meta)communicational messages, or, in any case, be an integral part of such endeavours. Thus, I shall approach intermedial references in such a way as to highlight (and, subsequently, analyse) not only their ability to connect two (or more) works of art, but also their capacity to give rise to a metareferential discursive level (via their transformative actions).

This process can be said to echo aspects of Gérard Genette's notion of transtextuality, defined as "all that sets the text in a relationship, whether obvious or concealed, with other texts" (Genette 1997, 1). This concept (which is in turn derived from Kristeva's intertextuality) was conceived to analyse literary phenomena. As Pethő points out, it is improper to think of films as texts, when in fact they more closely resemble textures because of their inherent multimodality and primacy of synesthetic perception (visual, aural, haptic, etc.) (2011, 69). Adapting Genette's model for use in film studies can, in my opinion, still be rather useful, as long as it is not taken ad literam. He proposed five specific variants: intertextuality (seen as the copresence of a text within another), paratextuality (the relationship between the text and its paratexts such as a title, subtitle, preface, postface, etc.), architextuality (the relationship between a text and the genre of texts that it is part of), metatextuality (the critical relationship between two texts) and hypertextuality (the transformative relationship established between two texts). It is precisely this last variant that is of interest here. Genette defined it as: "any relationship uniting a text B (which I shall call the hypertext) to an earlier text A (I shall, of course, call it the hypotext), upon which it is grafted in a manner that is not that of commentary" $(1997,5)$. In addressing the difference between intermediality and intertextuality, Yvonne Spielmann highlights that "where intertextuality expresses a text-text relationship, intermedia means that the reference frame of the entire system of art forms that mediates the intermedial correlation is itself included in the processes of transformation” (quoted in Pethő 2011, 39). I shall attempt to use part of Genette's insights to better understand (1) the ways in which two works of art from different mediums can be interlinked with one another, (2) how this 
process inevitably implies a series of transformations, and finally (3) how these transformative operations could be used to articulate a higher-level discourse centered on the cinematic and painterly object-levels.

Jürgen Heinrichs and Yvonne Spielmann put forth the hypothesis that the cinematic medium "highlights the transformative quality of intermediality that can be found in the varying interrelationships between two or more media forms" (quoted in Pethő 2011, 29). Thus, cinema can be viewed as an ideal receptacle for all manner of intermedial exchanges. In what follows, I propose considering only intentional instances of such intermedial references.

We must first highlight the distinction between incorporating a painting directly into the film and reconstructing it through various means (hinting at it, without using it as such). In the former case, we have what Genette would have called proper intertextuality because the material painting is (re)presented in the film in more or less a direct manner. Filming a painting implies transferring it into another medium while keeping it as close as possible to the source (thus, keeping the level of alterations to a minimum), there is a certain degree of fidelity. In all other cases, when such a direct citation is missing, but the reference is still discernible, we are confronted with what one might call transformative incorporation. It would easily correspond to an intermedial variant of Genette's hypertextuality, because such an instance invites the viewer to attempt to precisely map out the alterations and transformations that the transfer process involved. This type of referencing a painting within a cinematic work, but without directly remediating the painterly artefact implies a "reconstruction" of the painting's main characteristics and components (subject, composition, lighting, etc.) using various cinematic elements. It can be done using actors, shadows, natural landscapes, various materials, such as paint, sand, paper, or it can even be entirely hand-drawn.

One of the most interesting ways by which to achieve this effect is having real actors pose as the characters from a specific painting. This transformative technique is called tableau vivant. Brigitte Peucker considers it as the paroxysm of the intermedial nature of cinema itself, as "a meeting point of several modes of representation, constituting a palimpsest or textual overlay simultaneously evocative of painting, drama, and sculpture" $(2003,295)$. This staging of paintings using real actors involves a type of embodiment of the inanimate image: "the introduction of the real into the image - the living body into painting —and thus attempts to collapse the distance between signifier and signified" (Peucker 2003, 295). Thus, this technique implies a (semiotic) exploration of the nature of painterly representation, and its relationship with cinematic representation. 
This view is shared by Steven Jacobs in his historically centred study on tableaux vivants. He states that using this particular device, "filmmakers attempted to determine the specificity of their medium - movement was juxtaposed with stasis, pictorial or sculptural space with cinematic space, iconic immediacy with filmic duration, and so forth" $(2011,94)$. To sum up: the tableaux vivants can be thought of as a nodal point of several representational modes, thus a prime source of cinematic self-reference (and, by extension, metareference).

\section{Painterly References as Metareferences}

In order to better understand the potential metareferential uses of tableaux vivants in narrative cinema, we can turn to the work of Werner Wolf, who proposes a unique categorization of this type of phenomenon. In a classical semiotic framework, intermediality would be deemed as an example of metareferentiality signs that reference other signs (Nöth 2009, 62-63) -, but Wolf deliberately alters this terminology.

In his proposed transmedial model, he deems metareference as an example of self-reference (as opposed to hetero-reference), defining it as the quality of signs (or sign systems) to "point to" themselves or other signs (or sign systems). That is to say, he distinguishes between intra-compositional self-reference (such as mise en abyme or metalepsis) and extra-compositional self-reference (such as intertextuality or intermediality) on the grounds that the referential process in the case of the former is directed inwards (to elements of the work itself), whereas in the case of the latter it is directed outwards (to elements from other works) (Wolf 2009, 38). Metareference is to be understood as a specific variant of self-reference. He distinguishes between the mere presence of a self-referential instance in a work of art (by which we understand any sign or configuration of signs that points to itself or the semiotic system it is a part of) and the instrumentalization of such a device as to construct and sustain a commentary on the work of art, or the entire medium - on a higher logical plane, a meta-level (Wolf 2009, 15-20). Although these alterations to the classical terminology can cause some difficulties, the benefits may very well outweigh the downsides. ${ }^{1}$ Because of this additional focus on hierarchical distinctions between the various discursive levels, one can begin to approach all manners of cinematic instances that would otherwise not have been taken as an instance of "reflexivity" on the ground that they are not thematically linked to the cinematic process (see Stam 1992).

1 This paper will, in part, try to make the case for such a terminological shift. 
In cinema studies, painterly can designate any "technical or compositional effect that results in the visibility (and non-transparency) of the 'surface' against the 'scene'” (Pethő 2011, 180). It can be thought of as a way of highlighting the formal aspects of the filmic artefact, eliciting firstly a form of medium-awareness in the viewer and then enabling him/her to reconstruct a higher-level discourse pertaining to that specific artwork or to the medium in general. Thus, these instances of extra-compositional references (which I have dubbed intermedial transformative incorporations: as exemplified by tableaux vivants) can become metareferential when they are used not only to link two works of art, but to create higher-level reflexive discourses.

Before we can dive into the analysis, we must consider a notion that has been intrinsically linked to metareference, namely aesthetic illusion. It is defined as a pleasurable cognitive response of the addressee of a work of art (Wolf 2013, 51-52). Aesthetic illusion is intertwined with what S. T. Coleridge famously called "the suspension of disbelief." ${ }^{2}$ It is a pleasurable reaction to experiencing a work of art, and the basis of what makes that work's fictional representation of reality to be taken not as artifice, but (at least for a time) as a possible reality. Theorists such as Robert Stam (1992 [1985]), Christian Metz (2016 [1991]) or Christopher Ames (1997) have linked metafilmic practices to the act of illusion-breaking, following a line of thought that originated in Bertolt Brecht's theatrical poetics. This highly reflexive "other tradition" (Stam 1992, xi) is opposed to the realistic and naturalistic "transparency" of (cinematic) representation.

According to Wolf though, metareferential devices can be used either to strengthen the aesthetic illusion or to disturb it. When the illusion is shattered by such a device, the artifice becomes visible and the whole artistic apparatus becomes the subject of attention and inquiry. I adhere to Wolf's claims in saying that, while these metareferential devices can be used in an illusion-shattering manner, it is not always the case. When a painting appears within the narrative of a motion picture, it can simply be there as part of the representation of the fictional world. This applies to those instances when a film's prime interest becomes the prop-like nature of the aforementioned painting. In contrast to intramedial references (i.e. the appearance of a film within another film), intermedial references are important components to the believability of the constructed representation of that fictional universe. They not only create but maintain the aesthetic illusion throughout the entire duration of

2 Coleridge uses this famous phrase in Chapter XIV of his Biographia Literaria (1817). The text is available online, here: https://web.english.upenn.edu/ mgamer/Etexts/biographia.html. Last accessed 26. 08. 2020. 
the movie. When the prime concern is not verisimilitude (the inconspicuous nature of a painting on a wall in the background of a scene), but the fact that the mere presence of the painting within the represented world is used to highlight or reveal some aspects of the cinematic artefact (prompting a meta-awareness in the viewer), then we can call it metareferential. If its presence is blatantly foregrounded in such a manner as to violently contrast with the cinematic sequence it is a part of, or if it is used in such a way as to highlight the artificial nature of the representation, then we can conclude that its main goal is to disrupt the viewer's immersion, prompting a response/reaction to the scene (and by extension to the film as a whole).

As Steven Jacobs points out, in the context of narrative fiction films, tableaux vivants can be rather ambiguous: "because of their aestheticisation of immobility, they create blockages in the flow of a narrative film that result in a kind of enigma" (2011, 95). One can see that their staged and artificial nature seems almost specifically designed to potentially shatter the cinematic aesthetic illusion, but even such moments of arrest, if contextually motivated, can nonetheless strengthen the fictional world's hold on the viewer. It is for this precise reason that a case by case analysis is needed.

The following are a series of brief case studies in which I shall attempt to investigate two films which use tableaux vivants in order to encode or foreground the presence of metacommunicational statements: Peter Greenaway's A Zed and Two Noughts (1985) and Lars von Trier's The House that Jack Built (2018). I shall be analysing two very different ways of employing intermedial transformative incorporations, looking at their metareferential potential, and attempting to decode their meaning.

\section{An Intermedial Detour: A Zed and Two Noughts (Peter Greenaway, 1985)}

Peter Greenaway has famously stated that "cinema is dead" (which is also the title of a lecture he delivered on multiple occasions around the globe ${ }^{3}$ ). What does he mean by this? He views cinema in terms of a conglomerate of mediums, all interconnected by text. Text has been, in Greenaway's opinion, the fundamental building block of cinema, not the image (as one might think). He argues that since virtually all films start their life with a written screenplay, films are nothing more than illustrations of text (Gras and Gras 2000, 173). In the same lecture, the British director claims that although cinema was invented well over a hundred years before, there have 
not been that many actual films made. By this, he means image-based films, films that are held together not by the text they originated from, or by the text projected on-screen (in the form of intertitles), or by the dialogue spoken out loud by the characters represented in the image. His stance is certainly powerful, but one cannot help but question such statements coming from a director whose films abound in text (or instances that foreground the visual aspect of writing: carefully arranged rows of infinite lists or instances of calligraphy overlays). Greenaway's films can be thought of as symptomatic of the crisis of images that he pontificates about. Their idiosyncratic use of text (that, in Barthes's terms, does not anchor the images it accompanies) and unique visual style make them perfect candidates for exploring the limits of narrative cinema. Greenaway's films do not take the leap between a textbased cinema and an image-based cinema, but stand defiantly in-between, engaging (be it mockingly) with the various problems that each of them brings forth.

Greenaway's filmography abounds in instances of metareferentiality, as I have explored elsewhere (Drăgan 2017), but this paper centres upon the intermedial relationship between cinema and painting, so I shall attempt an in-depth analysis of such an instance from his 1985 feature, A Zed and Two Noughts.

The film is centred around the lives of two brothers who work at a zoological garden, and the various company they keep. It is a collection of interlocking narratives, each focused around one of the characters. One such side-narrative concerns a dubious surgeon, van Meegeren, with an obsession for copying the works of the Dutch painter Johannes Vermeer. It is on this rather odd (and some may say unimportant) subplot that I'll be focusing my attention. The entire story is presented in only 4 or 5 scenes scattered throughout the film and thus the overall effect is one of diluting its impact. On first viewing, it seems but a brief (and selfindulgent) accolade, but this is not entirely true. Brigitte Peucker postulates that "one reason for Vermeer's centrality for the art of filmmaking lies with the enigmatic image of the woman, an image that is voyeuristically explored by artist and filmmaker alike" $(2003,297)$. She continues by stating that "by way of this tableau vivant of The Artist in His Studio, then, the distinct temporalities of three modes of visual representation are juxtaposed: the celebrated 'phenomenon of temporal stasis' implied in Vermeer's paintings is marked by the punctum of photography, and subverted by the devolution of narrative in cinema and theater" $(2003,302)$. While agreeing with this interpretation, I contend that Greenaway's intermedial poetics of cinema is foregrounded in a more direct manner, using metareferential statements. What follows is further proof of such a connection between Vermeer and Greenaway, via an encoded discourse hidden in plain sight. 
The scenes in question feature a series of recreations of famous Vermeer paintings (using various characters from the film). As Jean Petrolle points out in his essay on Greenaway, the specific paintings that are recreated (The Allegory of Painting and The Music Lesson) are not chosen at random. These are Vermeer's most selfreferential images in his whole body of (known) work (Petrolle 2008, 160). This deliberate act of choosing such works brings to light a possible interpretation, namely that these scenes of image-making can be thought of as exploring the way in which the filmmaker constructs the cinematic representation.

This line of thought can be further elaborated. Why Vermeer and not another painter? Greenaway himself (in the introduction to the DVD release of this film ${ }^{4}$ ) cites Jean-Luc Godard, who famously called Vermeer the world's first cinematographer because of his way of manipulating light. But if the scenes in question are only supposed to be a mise en abyme of sorts, why does it feel like there is not much information imparted on the actual process of creating this film? I hypothesize that these scenes are but indirectly about the act of Greenaway's own filmmaking (as commentators, such as Peucker, would suggest), and in fact about Vermeer himself (more precisely, about his technique of image-making). In Greenaway's film, there is (as it has already been mentioned above) a disjunction between text (be it written or spoken) and image. Following only the text seems to lead nowhere in understanding the specificities of each story told. Another one of Greenaway's famous bold statements is that "most people are visually illiterate" (introduced in his lecture and also later reused as part of his 2008 documentary, Rembrandt's J'accuse). So, in keeping with what is obviously a personal dissatisfaction with verbal/textual communication, in favour of an image-based system, I assume it is not beyond the realm of possibility that he would encode some messages using images (and not texts).

I suggest that these scenes that reference Vermeer's work are in fact a personal statement about the way in which this fascinating painter constructed his images. In the scene that reconstructs the famous work, The Allegory of Painting, we see two characters sitting in a space which is made to resemble (but not exactly replicate) the room depicted in the painting [Fig. 1]. The tableau vivant fills the entire space of the screen, all the main constitutive elements of the original painting having been reconstructed using the characters from this film. It is a conscious endeavour organized by the character of van Meegeren, thus fully diegetically motivated. But, I posit that the transformations operated (all the alterations to the original 
composition) are the ones that need to be taken into consideration: the woman (posing as the muse) is wearing a red hat (evoking another famous work by Vermeer, Girl with a Red Hat) as she strikes a similar pose as the one in the aforementioned painting; the surgeon dressed as the painter in the painting (presumably a selfportrait by Vermeer) is not behind an easel, but a photo camera. This latter is the most important difference.

Greenaway seems to be using this intermedial reference to the famous Vermeer painting to signal to the audience that this character is to represent the famous Dutch painter (for all extensive purposes, in this brief scene, the surgeon van Meegeren is to be taken as Vermeer). And what is this Vermeer doing? The painter is taking a photo of a girl with a red hat, a second intermedial reference to another of Vermeer's paintings, The Girl with the Red Hat. I posit that this second reference grafted almost seamlessly to the entire composition of the tableau vivant is used here (1) to signal its presence, as a disruption in the transfer process, and (2) to spell out Greenaway's own position on the famous debate surrounding Vermeer's modus operandi. The fact that van Meegeren, the would-be painter, standing in for Vermeer, is using a photo camera can be read as Greenaway's taking the side of those art historians and scholars who brought forth the idea that Vermeer himself made use of some sort of optical apparatus in the construction of his images (such as Philip Steadman (2002), who proposed that Vermeer used a camera obscura, or the artist David Hockney and the physicist Charles M. Falco, who have made similar remarks in their 2006 book, Secret Knowledge: Rediscovering the Lost Techniques of the Old Masters). This layering of metareferences (coded by allusions to Vermeer's paintings) can be viewed as Greenaway's attempt to communicate a personal opinion (in what still is an ongoing debate on Vermeer's technique ${ }^{6}$.

The entire metareferential instance seems not to be directly aimed at the movie as such but at the medium of painting, which in turn directly influenced cinema (and certainly Greenaway himself, being that he was formally trained as a painter). In Wolf's words, such an "extra-compositional metareference to a field (type), of which the work in question is also a part (a token), indirectly also implies a metareference to the work in question, albeit by means of a detour" $(2009,38)$. In this case, this particular detour takes us through 17th-century Dutch art, but nonetheless returns to the film as such, for, as noted above, Greenaway has admitted on numerous occasions that the work of Vermeer constituted an indispensable

$6 \quad$ A debate that gave rise also to a hands-on approach by Tim Jenison, who decided to test some of the techniques put forth by diverse scholars, an effort documented in the form of a 2013 feature called Tim's Vermeer, directed by Teller. 
source of inspiration. In one of the bonus featurettes of the film's DVD, the director talks openly about Vermeer's legacy in the context of his film: numerous lighting ideas being directly borrowed from the artist's works. ${ }^{7}$

Without affecting the aesthetic illusion, this instance of the tableau vivant (that contains, as I have shown, a layering of two intermedial references to two painterly works) is used to encode a double-layered message: one personal statement from the director about the artist in question, Vermeer - and the debate surrounding his particular technique; and another statement about the status of cinema in general, as indebted to artists like Vermeer, whose everlasting legacy is at all times present in the "texture" of each and every film.

\section{The Illusion-Shattering Shot: The House that Jack Built (Lars Von Trier, 2018)}

Lars von Trier is a filmmaker whose work abounds in cinematic experimentation. In doing so he tends to attack the preconceived notions of his audience. He employs Brechtian techniques (the set design in Dogville [2003] being the most evident example) in order to make the film artefact "visible" to those who watch it. His films contain a tension between the immersive qualities of the stories he tells and the distancing aspects of the way he tells them, in a way totally adhering to the idea of a reflexive cinema put forward by Robert Stam, who states that Brecht's proposed subversive écriture "can be employed in the demystification of any oppressive society or any reigning ideology" $(1992,212)$. This opposition to a kind of "reigning ideology" seems present in von Trier's 2018 feature as well, more precisely, an opposition to the general backlash that previous films of his (such as Antichrist, 2009, or Nymphomaniac, 2013) had received from critics and audiences alike. ${ }^{8}$

The House that Jack Built centres on the life and "career" of a serial killer, beginning with his very first instance of homicide, tracking his most accomplished murders over the years, and finally letting us see how he fails to complete his last venture - testing a device designed and constructed by him, intended to end the lives of multiple people at once. From a narrative standpoint, the movie is a frame story, with the titular Jack explaining to some unknown person (by the name Verge) how he committed some of his finest crimes. In the movie's epilogue, we find out

7 https://www.youtube.com/watch?v=LnSnmx3BaT4\&t. Last accessed 26. 08. 2020.

8 To name only a few examples: https://www.theguardian.com/film/2009/jul/16/antichrist-larsvon-trier-feminism; https://jezebel.com/i-watched-nymphomaniac-volume-1-on-demand-soyou-dont-1538905517; https://newrepublic.com/article/117070/lars-von-triers-nymphomaniacconventional-sexist-film-review. Last accessed 26. 08. 2020. 
that Verge is none other than the poet Virgil from Dante's The Divine Comedy, who has come to escort Jack to hell.

Lars von Trier appears to have made this movie not only to tell a series of disturbing accounts of gruesome murders (thus confining it to the filmic genre known as "torture porn"), but also to communicate to the viewers his personal opinion on the way in which they should approach his entire body of cinematic works - incidentally packed full of disturbing tales. This is by no means an "interpretive stretch," the director's intentions being rather evident especially in the scene where Jack, the protagonist, presents us with a montage of shots from von Trier's earlier films with the voice-over directly commenting on the aesthetic appreciation of representations of violence in art (which is in itself a nod to Thomas De Quincey's famous On Murder Considered as one of the Fine Arts, 1827, where a similar topic is discussed: the aesthetic appreciation of murderous acts). Jack refuses the assumption that fiction (and, by extent, art in general) is an indispensable tool for understanding, containing and keeping in check humanity's cruelty. He instead advocates for an artistic appreciation of the act of destruction, decomposition and even of the degradation of matter itself. To substantiate his claims, Jack cites, among others, Albert Speer's theory of the "ruin value" $(1970,56)$. Jensen Suther puts a radical idea such as this in direct relation with some of Lars von Trier's own controversial statements:" "by re-inscribing his own scandalous gesture into his cinema, von Trier begins to subject the violence of his cinema to critical reflection and, perhaps in spite of himself, to combat his own theatrical tendencies" (Suther 2019). Thus, one can see how von Trier's film functions as a sort of indirect rebuttal of the accusations that his cinema is merely an excuse to flaunt his own (repressed) violent tendencies. Whether or not this proposed nihilistic lens is indeed the "correct" way through which he wishes his oeuvre to be interpreted still remains open to debate. What is certain, however, is that this film invites (or, indeed, almost forces) the viewers to critically reconsider their relationship with his cinema.

I propose analysing how the director uses filmic techniques to articulate this higher-level discourse. And how in this metacommunicative act, a painterly reference in the form of a transformative incorporation (a tableau vivant), acts as the keystone of the entire endeavour.

Firstly, the director employs a series of Brechtian, or more specifically, Brechtianinspired techniques (because his aim is not solely political in nature, but self-

9 He is of course referring to a 2011 incident where the director said that he "is a Nazi." (Cf. https://www.theguardian.com/film/2011/may/18/lars-von-trier-cannes-2011-nazi-comments. Last accessed 26. 08. 2020.) 
reflexive nonetheless). As Stam points out, Brecht's "distancing effect" was brought about by a series of operations, such as employing an interruptive, fractured, or digressive narrative structure (Stam 1992, 213). The House that Jack Built is, indeed, constructed as a frame story, thus cultivating ellipses and hiatuses in the narrative flow. There are also many abrupt halts, which give rise to entire digressive segments, in which Jack explains himself to his companion, Verge. These interruptions are present not only at the level of the voice-over, but also visually. When Jack starts to ramble on, for example, about the differences between Romanesque arches and Gothic ones, we are presented with a series of documentary-like images that have the role of visualizing (by way of diagrams) the physical and aesthetic qualities of this architectural innovation. The entire film abounds in such moments that distract the viewer from the actual story and affects the immersion, in a way adhering to what Stam would qualify as reflexivity: "art should reveal the principles of its own construction, to avoid the 'swindle' of giving the impression that fictive events were not 'worked at' but simply 'happened"' (1992, 213). The film also appears to foreground its heterogeneous medial nature in a similar Brechtian fashion. It seems to probe or dissolve the limits/boundaries of its own medium, continually referencing its palimpsestic nature. It does this by incorporating a plethora of references to high culture and popular culture alike: such as the entire reworking of Dante Alighieri's Inferno, citing the poems of William Blake, incorporating works by Paul Gauguin, Juan Gris, or children's cartoons, drawings, photos, found footage, historical news footage, musical performances by Glenn Gould, scenes from the director's own films, architectural diagrams, pop music, etc.

Secondly, I propose that von Trier resuscitates and indeed transmedially employs a long debunked notion in narrative theory, namely Käte Hamburger's so-called markers/signs of fictionality. The term was introduced by Hamburger to signify the specific ways in which a work of fiction signals its own fictionality to its readers, in other words, that there "are certain specific characteristics of fictional discourse, and that fictional discourse is ontologically fundamentally different from 'normal' or non-fictional discourse” (Bareis 2008). Gérard Genette does not contest the existence of such markers, but argues against their functionality in accurately distinguishing a work of fiction from a work of non-fiction (1993, 54-84).

I shall try to identify and ascertain how some of the narrative techniques employed could (by way of their institutionalized usage in movie-making) potentially function as markers/signs of fictionality, and how their usage might be employed by the filmmaker in a metareferential manner. Lars von Trier appears to make use of specific techniques (in a way similar to the situationists' notion of détournement) 
in order to convey to the viewer multiple times (1) that the events depicted are not real (as opposed to the majority of narrative fiction which tries to obscure this fact) and (2) that the ideas brought up in this film are intended to be applied to his whole body of work.

One instance of such a marker of fictionality is the fact that all the episodes presented in the film are narrated by Jack in voice-over (in fact, one can argue that the film employs two narrators, given the fact that Jack is permanently interrupted by Verge). We are introduced to the setting of each murder by Jack's words, then we are left to interpret the flow of images as the direct result of Jack's enunciation. This technique of melting together the spoken narration with the sequence of images is not, by any means, uncommon, being used throughout film and TV productions (a famous example being the opening sequence of Peter Jackson's The Lord of The Rings, which blends these two types of narration ${ }^{10}$ ).

Another marker of fictionality might be the film's structure: on the one hand, frame stories are a staple of fictional narratives (from Chaucer to Boccaccio, etc.), and on the other, the fact that each episode (each story within a story) is further divided into chapters, each visually separated from one another by a title card (e.g. the first one is called: "1st INCIDENT").

One could interpret the direct reference to Dante's Inferno as a potential mark of fictionality. By using as one of its main characters a famous fictional representation of a historical figure (Verge being none other than the Roman poet Vergil/Virgil/Vergilius), as did Dante in his Divine Comedy, the film establishes itself as a work of fiction. This interpretation can be countered by the psychological line of thought which may posit Verge's presence as a "mere" projection of Jack's torn psyche. This may very well be the case, but I propose that the film makes use of another intermedial reference in order to highlight the artificial (and hence fictional) nature of Virgil's presence here: the reference to Eugène Delacroix's 1822 painting, The Barque of Dante.

Indeed, the scene in question is undoubtedly an example of transformative incorporation, by way of the technique of tableau vivant: Delacroix's painting is reconstructed using the characters from the film. Furthermore, the scene is comprised of just one static shot [Fig. 2], making it seem more like a painting. Lars von Trier's reconstruction can be seen as both a marker of fictionality (by which the juxtaposition of the painterly and cinematic foregrounds the latter's fictional nature), and a Brechtian "distancing effect" (by which the artificial nature of representation in general is foregrounded). This is why I consider this tableau vivant the keystone in the film's metarefrential discourse.

10 https://www.youtube.com/watch?v=aWKHhb2q-oc. Last accessed 06. 03. 2021. 
As for the transformative elements, one can clearly discern that this CGI-aided scene was masterfully crafted in order to include an enormous amount of similarities, trying its best to recreate Delacroix's painting as truthfully as possible. Indeed, the level of detail is astounding, from the virtually identical setting to each of the characters' stances completed by accurately pictural folds in their robes - a modernday example of Aby Warburg's notion of "Pathosformel" (Warburg 2010), and presenting an almost identical lighting setup. For all extensive purposes, this scene seems to have been conceived not as a commentary on the painting by Delacroix, but simply to graph the two characters from the film onto the "surface" of the painting (almost akin to a metaleptical instance). This is to say that the metareferential discourse it entails, or signals, is not directed at the painting, but directly back to the film itself. In this case, the intermedial detour is considerably shorter than what we see in Greenaway's film. Thus, we are invited to compare the scene to the rest of the film and consider its place and subsequent meaning within it as a whole.

In this sense, this sequence's formal aspects are meant to stand out from the rest of the film's gritty, dogma 95-inspired aesthetic (mostly comprised of shaky handheld camera work and intentionally sloppy editing). It is the same composition and framing as the painting, being lit in a similar (though somewhat bolder and more direct) manner. To heighten the painterly aspect of this scene (and make the link between the two mediums even more clear) the whole scene was shot with a high frame rate and then slowed down a great deal. That is why the figures appear to move ever so slightly, while at the same time giving the impression of stillness.

Ágnes Pethő highlights that "focusing on the sheer visual pleasure of stillness means becoming conscious of the single image in cinema and experiencing its double release from: a) being inscribed within and subsumed by narrative flow, and b) from experiencing it primarily as an index of a pro-filmic reality, thus experiencing its 'imageness' as something more opaque” $(2013,68)$. Lars von Trier's tableau vivant appears to function in the same manner, at once distancing itself from the rest of the film it is a part of and rendering itself as a profoundly "opaque" moment. This arrested moment in the film's narrative flow functions as an agent of disruption.

In contrast to the other example presented in this paper (the scene in Peter Greenaway's film), this instance of intermedial reference shatters the aesthetic illusion. It does so by presenting itself in contrast to the sequences that precede it. The presence of this particular shot in a montage of shots depicting the characters' descent to hell makes a mockery of the whole scene "because the grandeur of the nineteenth-century style clashes with Jack's general lowliness" (Suther 2019). Its comical effect is used to signal to the viewer that this film should not be taken at 
face value, but as a meta-commentary by von Trier himself (on himself and on the way he himself thinks his films need to be approached). This instance of disrupting the aesthetic illusion is different than his use of set design in Dogville (where the point was to test the audience's capacity of ignoring all obstructions put in their way in order to follow a story).

In the case of The House that Jack Built, it's narrative functions more or less as a stand-in for the director's entire body of cinematic works. The film constantly shifts its focus from immersing the audience into its fictional world, to making them aware of the metareferential discourse. Lars von Trier seems to use this subject matter not to explore the nature of homicide, but to encode (by way of analogy) a personal stance on his entire oeuvre. In rehashing the whole plot of Dante's Inferno alongside a couple of tales of gore and murder, he attempts to concurrently grab our attention (by way of such subject matter, appealing to both ends of the cultural spectrum) and direct it toward this discourse: a simultaneously combative and apologetic ars poetica. While inviting the viewer to decide whether or not to adhere to his proposed interpretative stance, von Trier's main goal seems focused on prompting a (re)consideration of his work.

\section{Conclusions}

I have tried to make the case that painterly references, more precisely transformative incorporations such as tableaux vivants are an indisputable way in which a filmmaker can encode metareferential (that is to say, higher-level logical) statements about their works, or the status of the cinematic medium in general. As the two examples have shown, it is not necessarily a prerequisite that such statements disrupt the aesthetic illusion of film, but what is needed in order to decode such messages is a specific insight into the general processes of image making. That is not to say that without such knowledge one could not notice the encoded statement's presence (in the case of the scene in Lars von Trier's film, its presence is disruptive, almost calling out to be considered and interpreted), but deciphering it would become rather cumbersome. The main signifying source of such transformative incorporations is indeed the plethora of differences (or, in some cases, similarities) to the painterly work referenced. This is why a technique such as the tableau vivant is a veritable treasure trove when it comes to encoding information in a purely visual manner, because all instances of its use necessarily entail the modification, alteration, and distortion of the source material. 


\section{References}

Ames, Christopher. 1997. Movies About the Movies: Hollywood Reflected. Lexington: University Press of Kentucky.

Bareis, J. Alexander. 2008. The Role of Fictionality in Narrative Theory. In Narrativity, Fictionality, and Literariness. The Narrative Turn and the Study of Literary Fiction, eds. J. Alexander Bareis and Lars-Åke Skalin, 155-175. Örebro: Örebro University Press.

Drăgan, Cristian. 2017. Metacinemaul lui Peter Greenaway [The Metacinema of Peter Greenaway]. https://istoriafilmului.ro/articol/metacinemaul-lui-petergreenaway/. Last accessed 19. 02. 2020.

Genette, Gérard. 1993. Fiction and Diction. Ithaka and London: Cornell University Press.

Genette, Gérard. 1997. Palimpsests: Literature in the Second Degree. Lincoln and London: University of Nebraska Press.

Gras, Vernon and Marguerite Gras, eds. 2000. Peter Greenaway: Interviews. Jackson: University Press of Mississippi.

Hockney, David. 2006. Secret Knowledge: Rediscovering the Lost Techniques of the Old Masters. New York: Avery Press.

Jacobs, Steven. 2011. Framing Pictures: Film and the Visual Arts. Edinburgh: Edinburgh University Press.

Metz, Chrsitian. 2016 [1991]. Impersonal Enunciation, or the Place of Film. New York: Columbia University Press.

Nöth, Winfried. 2009. Metapictures and Self-Referential Pictures. In Metareference across Media: Theory and Case Studies, ed. Werner Wolf, 87-120. Amsterdam New York: Brill/ Rodopi.

Pethő, Ágnes. 2011. Cinema and Intermediality: The Passion for the In-Between. Newcastle upon Tyne: Cambridge Scholars Publishing.

Pethő, Ágnes. 2013. The Vertigo of the Single Image: From the Classic Narrative "Glitch" to the Post-Cinematic Adaptations of Paintings. Acta Universitatis Sapientiae, Film and Media Studies vol. 6: 65-90.

Petrolle, Jean. 2008. Z is for Zebra, Zoo, Zed, and Zygote, or Is It Possible to Live with Ambivalence? In Peter Greenaway's Postmodern/Poststructuralist Cinema, eds. Willoquet-Maricondi, Paula, Mary Alemany-Galway. Lanham, Md.: Scarecrow Press. 
Peucker, Brigitte. 2003. Filmic Tableau Vivant: Vermeer, Intermediality, and the Real. In Rites of Realism: Essays on Corporeal Cinema, ed. Ivone Margulies, 294315. Durham-London: Duke University Press.

Speer, Albert. 1970. Inside the Third Reich. London: Weidenfeld \& Nicolson.

Stam, Robert. 1992 [1985]. Reflexivity in Film and Literature: From Don Quixote to Jean-Luc Godard. New York: Columbia University Press.

Steadman, Philip. 2002. Vermeer's Camera: Uncovering the Truth Behind the Masterpieces. Oxford: Oxford University Press.

Suther, Jensen. 2019. The Art of Murder: What We Have to Learn from The House That Jack Built. https://www.sensesofcinema.com/2019/feature-articles/the-artof-murder-what-we-have-to-learn-from-the-house-that-jack-built/. Last accessed 26. 08. 2020.

Warburg, Aby. 2010 [1929]. Mnemosyne Einleitung [Introduction to Mnemosyne]. In Aby Warburg: Werke in einem Band [Volume of Works], eds. M. Treml, S. Weigel and P. Ladwig, 629-639. Berlin: Suhrkamp.

Wolf, Werner. 2009. Metareference across Media. The Concept, its Transmedial Potentials and Problems, Main Forms and Functions. In Metareference across Media: Theory and Case Studies, ed. Werner Wolf, ix-85. Amsterdam - New York: Brill / Rodopi.

Wolf, Werner. 2013. Aesthetic Illusion. In Immersion and Distance, eds. Werner Wolf, Walter Bernhart and Andreas Mahler, vii-63. Amsterdam - New York: Brill / Rodopi. 


\section{List of Figures}

Figure 1. A frame from Peter Greenaway's A Zed and Two Noughts which references The Allegory of Painting by Johannes Vermeer.

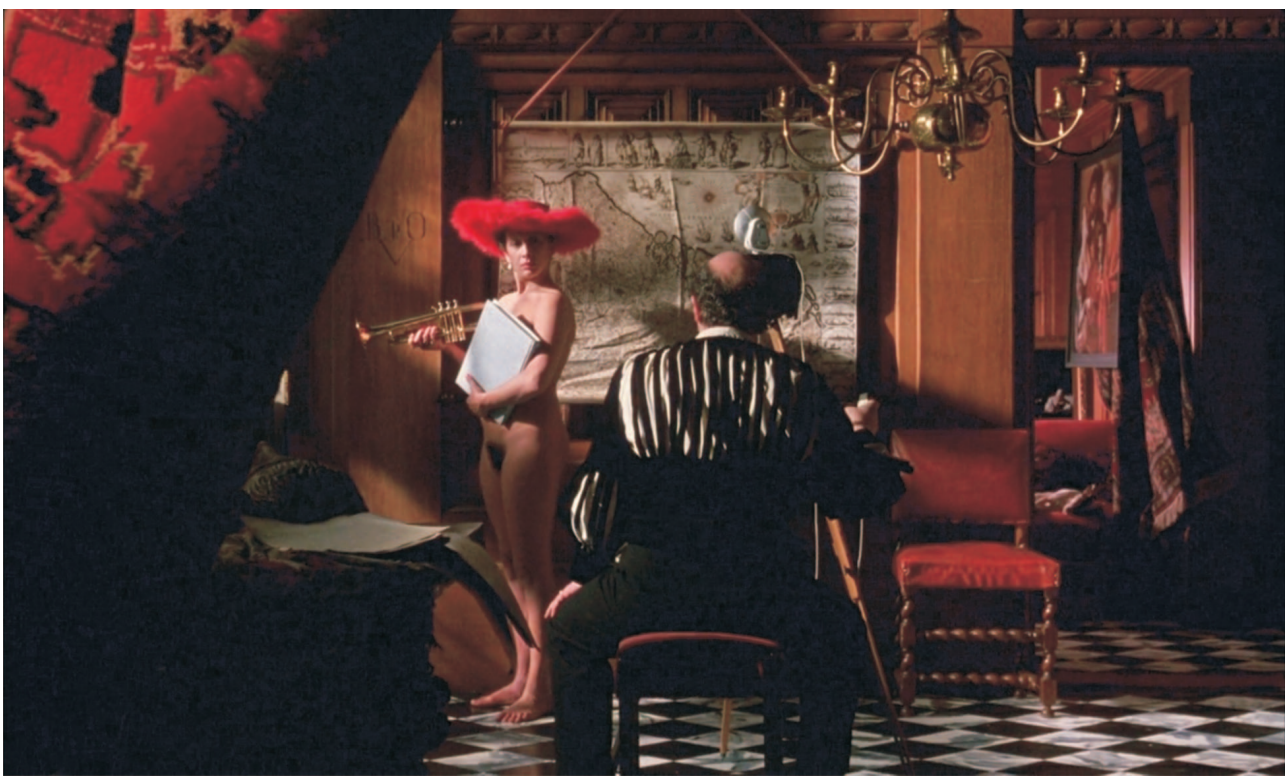

Figure 2. A frame from Lars von Trier's The House that Jack Built that reconstructs The Barque of Dante by Eugène Delacroix.

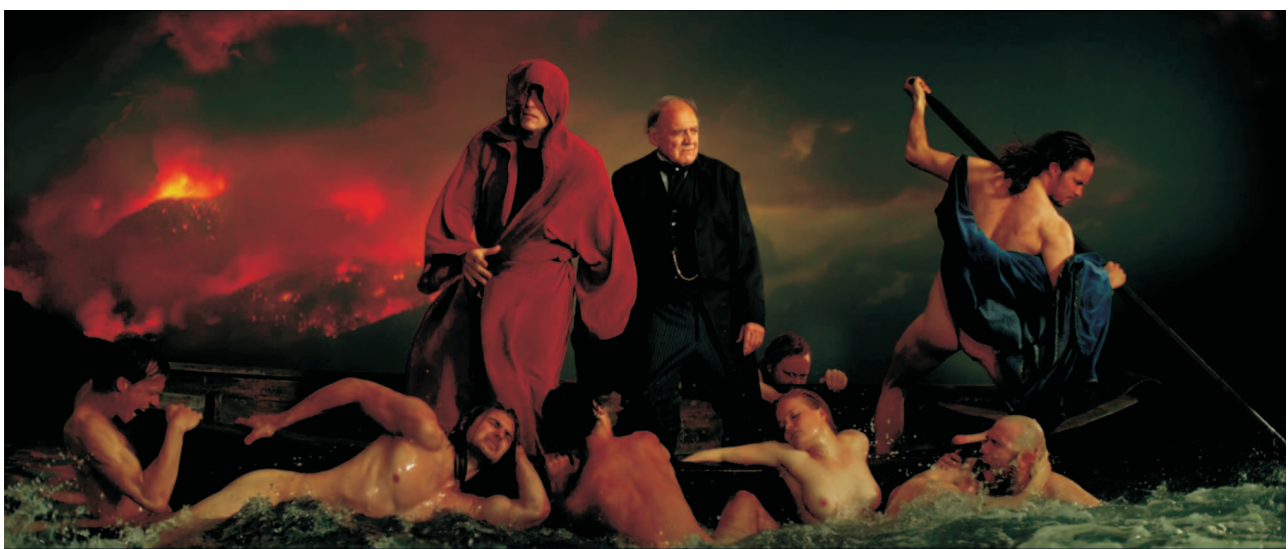

